\title{
Karakteristik Biochar pada Beberapa Metode Pembuatan dan Bahan Baku
}

\author{
(Biochar Characteristics Caused by Various Production Methods and Feedstock)
}

\author{
Dhea Pratiwi ${ }^{1}$, Syakur $^{1}$, dan Darusman ${ }^{1 *}$ \\ ${ }^{1}$ Program Studi Ilmu Tanah, Fakultas Pertanian, Universitas Syiah Kuala \\ corresponding author:darusman@unsyiah.ac.id
}

\begin{abstract}
Abstrak. Biochar merupakan arang hayati berpori (porous) yang berasal dari limbah organik (biomasa pertanian) atau sering disebut juga arang aktif yang melalui proses pembakaran tidak sempurna atau suplai oksigen terbatas (pirolisis). Pembuatan biochar menggunakan metode Kon-Tiki, soil pit, dan drum yang menggunakan bahan baku bambu petung, kayu pulai, dan tempurung kelapa. Beragamnya sumber bahan baku dan teknik pembuatan biochar dapat mempengaruhi hasil pertumbuhan dan produktivitas tanaman. Sehingga, perbedaan metode dan bahan baku sebagai pembuatan biochar penting untuk menentukan kualitas biochar. Penelitian ini bertujuan untuk mendapatkan jenis bahan baku (feedstock) yang mempunyai karakteristik yang baik dan mendapatkan jenis metode pembuatan biochar yang baik. Penelitian ini dilaksanakan di kebun percobaan dan laboratorium fisika tanah dan lingkungan Fakultas Pertanian Universitas Syiah Kuala sejak bulan Juni sampai Agustus 2019. Penelitian ini menggunakan Rancangan Acak Kelompok (RAK) Non Faktorial dengan 9 perlakuan dan diulang sebanyak 3 kali sehingga didapatkan 27 satuan unit percobaan. Karakteristik biochar yang diamati terdiri dari kadar air, zat menguap, kadar abu dan karbon terikat (fixed carbon). Jenis dan metode pembuatan biochar berpengaruh terhadap karakteristik biochar. Bahan baku (feedstock) biochar yang mempunyai karakteristik yang baik terdapat pada bambu petung, sedangkan metode pembuatan biochar yang terbaik terdapat pada metode Kon-Tiki.
\end{abstract}

Kata kunci: Biochar, bahan baku, metode pembuatan, karakteristik biochar

\begin{abstract}
Biochar is porous biological products originating from organic waste (agricultural biomass) or often called activated charcoal, results from incomplete combustion process or limited oxygen supply (pyrolysis). Biochar produced using the chamber of Kon-Tiki, soil pit, and drum with the feedstocks of petung bamboo, pulai wood, and coconut shell. Various sources of feedstock and techniques for making biochar might influence the yield of plant growth and productivity. Thus, differences in methods and feedstock for making biochar are important to determine the quality of biochar. This study aims to obtain the type of feedstock that has good characteristics and to obtain a good type of biochar production method. This research was conducted in the experimental research station of the Faculty of Agriculture, Universitas Syiah Kuala from June to August 2019. This study used a non-factorial randomized block design (RBD) with 9 treatments and repeated 3 times so that 27 experimental units were obtained. The characteristics of the observed physical properties of biochar consist of water content, volatile matter, ash content and fixed carbon.The types and methods of making biochar affect the characteristics of biochar. The feedstock of biochar which has good characteristics is found in petung bamboo, while the best method of making biochar is found in the Kon-Tiki method.
\end{abstract}

Keywords: Biochar, feedstock, production methods, characteristics of biochar

\section{PENDAHULUAN}

Iklim berhubungan erat dengan cuaca yang sering berubah, perubahan cuaca dan pemanasan global dapat menurunkan produksi pertanian antara 5-20\%. Iklim yang sering berubah secara umum terjadi disebabkan adanya peningkatan suhu yang signifikan (Ratnaningayu, 2009). Suhu yang terus meningkat disebabkan karena adanya kecepan suhu yang tidak mudah diperkirakan. Upaya mitigasi yang dilakukan untuk menghadapi perubahan iklim yaitu salah satunya meningkatkan sekuestrasi (proses penangkapan dan penyimpanan) karbon diantaranya dalam bentuk biochar (Lehmann et al., 2006). 
Biochar merupakan arang aktif berpori (porous) yang melalui proses pembakaran secara pirolisis (sedikit oksigen/keadaan oksigen terbatas (Anischan, 2009). Potensi bahan baku biochar tergolong melimpah yaitu berupa limbah sisa pertanian atau biomasa, terutama biomasa yang tidak mudah terdekomposisi dikarenakan rasio $\mathrm{C} / \mathrm{N}$ yang tinggi. Di Indonesia potensi penggunaan biochar cukup besar, dikarenakan bahan baku seperti limbah kayu, tempurung kelapa, cangkang sawit, bambu, tongkol jagung cukup tersedia (Tahir et al., 2008). Pada awalnya biochar dibuat dengan metode pirolisis lambat dalam keadaan oksigen terbatas dengan laju pemanasan dan suhu puncak yang relatif rendah (Sohi et al., 2009).

Pirolisis merupakan termolisis yang fungsinya yaitu melepaskan zat terbang (volatile matter) yang terkandung pada biomasa. Pada dasarnya zat terbang yang terdapat pada biomasa cukup tinggi. Bahan baku yang dikonversi secara pirolisis adalah bahan baku yang memiliki selulosa tinggi (Zaror \& Pyle, 1982). Hasil dari pembakaran biochar dapat langsung digunakan sebagai amelioran tanah. Biochar pada umumnya meiliki $\mathrm{pH}$ basa, C-organik dan banyak luas permukaan (Lehman et al., 2011).

Laju dekomposisi atau disebut juga dengan bahan organik yang melapuk tergolong tinggi, sehingga pembenah tanah organik alami yang diaplikasikan lebih bersifat sementara (temporary). Biochar digunakan sebagai bahan pembenah tanah alternatif. Biochar mampu lama bertahan di dalam tanah dan memiliki efek yang relatif lama, serta relatif resisten terhadap serangan mikroorganisme, sehingga proses dekomposisi berjalan lambat (Tang et al., 2013). Biochar yang berfungsi dalam bidang pertanian sangat bergantung pada karakteristik dari biochar itu sendiri. Biochar memiliki beberapa karakteristik antara lain seperi $\mathrm{pH}$, kemampuan mengikat air, C-total, kapasitas tukar kation (KTK). Bahan baku dan proses produksi biochar (jenis alat pembakaran, suhu dan lama pembakaran) yang berbeda dapat menghasilkan sifat fisik dan kimia biochar yang berbeda pula. Sehingga, dalam menentukan kualitas biochar dapat menggunakan perbedaan metode dan bahan baku sebagai pembuatan biochar.

Beragamnya sumber bahan baku dan teknik pembuatan biochar dapat mempengaruhi hasil pertumbuhan dan produktivitas tanaman (Lehman dan Joseph, 2010). Berbagai metode pembuatan biochar telah tersedia mulai dari menggunakan alat/metode tradisional sampai yang moderen. Penelitian ini mencoba untuk mendapatkan bahan baku yang mempunyai karakteristik yang baik dan mengetahui metode yang lebih efektif sebagai pembakaran biochar dari bahan baku yang bertekstur keras.

\section{METODE PENELITIAN}

\section{Rancangan Percobaan}

Penelitian ini menggunakan Rancangan Acak Kelompok (RAK) pola non faktorial. Percobaan dilakukan sebanyak 9 perlakuan dan diulang sebanyak 3 kali, sehingga akan menghasilkan 27 satuan percobaan.

\section{Pelaksanaan Percobaan}

Penelitian lapangan dilakukan di kebun percobaan Universitas Syiah Kuala, Banda Aceh. Penelitian dilaksanakan sejak Juni 2019 sampai Februari 2020. Analisis dilaksanakan di Laboratorium Fisika Tanah dan Laboratorium Penelitian Tanah dan Tanaman dimulai dari Juni hingga Agustus 2019. Penelitian terdiri dari beberapa tahap yaitu persiapan bahan dan alat pembuatan biochar, proses pembuatan biochar, teknis pengambilan sampel, dan analisis karaktersitik biochar. 


\section{Pengamatan dan Analisis}

Parameter pengamatan yang dianalisis yaitu kadar air, zat menguap, kadar abu, dan karbon terikat (fixed carbon) biochar

\section{HASIL DAN PEMBAHASAN}

\section{Kadar Air Biochar}

Uji sidik ragam menunjukkan bahwa perlakuan dari jenis dan metode pembuatan berpengaruh sangat nyata terhadap kadar air biochar. Rata-rata kadar air biochar akibat pengaruh jenis dan metode pembuatan disajikan pada Tabel 1.

Tabel 1. Rata-rata Kadar Air Biochar Akibat Pengaruh Jenis dan Metode Pembuatan

\begin{tabular}{lc}
\hline \multicolumn{1}{c}{ Perlakuan } & Kadar Air \\
\cline { 2 - 2 } P1 (Bambu Petung+Metode Kon-Tiki) & $\%$ \\
P2 (Bambu Petung+Metode Soil pit) & $16,67 \mathrm{~b}$ \\
P3 (Bambu Petung+Metode Drum) & $26,45 \mathrm{c}$ \\
P4 (Kayu Pulai+Metode Kon-Tiki) & $7,10 \mathrm{a}$ \\
P5 (Kayu Pulai+Metode Soil pit) & $10,78 \mathrm{a}$ \\
P6 (Kayu Pulai+Metode Drum) & $30,00 \mathrm{c}$ \\
P7 (Tempurung Kelapa+Metode Kon-Tiki) & $7,34 \mathrm{a}$ \\
P8 (Tempurung Kelapa+Metode Soil pit) & $11,11 \mathrm{a}$ \\
P9 (Tempurung Kelapa+Metode Drum) & $12,59 \mathrm{ab}$ \\
BNJ0,05 & $9,63 \mathrm{a}$ \\
\hline Keterangan: Angka yang diikut oleh huruf yang tidak sama berbeda nyata pada ui BNJ
\end{tabular}

Keterangan: Angka yang diikuti oleh huruf yang tidak sama berbeda nyata pada uji $\mathrm{BNJ}_{0,05}$

Rata-rata kadar air biochar akibat pengaruh jenis dan metode pembuatan setelah diuji dengan $\mathrm{BNJ}_{0,05}$ disajikan pada Tabel 1 menunjukkan bahwa jenis dan metode pembuatan berbeda sangat nyata terhadap kadar air biochar. Pada semua perlakuan biochar dapat dilihat bahwa jenis biochar bambu petung dengan beberapa metode pembuatan yaitu Kon-Tiki, soil pit, dan drum memiliki nilai rata-rata yang rendah dibandingkan dengan jenis dan metode pembuatan biochar lainnya, juga didapatkan nilai terendah pada perlakuan P3 (bambu petung dengan metode drum). Hal ini terjadi karena pada saat proses pembuatan biochar memerlukan waktu yang lama yaitu 65 menit dan bahan baku yang digunakan juga berbahan keras yang terdapat kandungan lignin. Menurut Hartanto et al. (2010), nilai kadar air bahan baku biochar dipengaruhi oleh terjadinya kontak langsung antara biochar yang memiliki temperatur yang tinggi dengan udara sekitar, sehingga biochar banyak menyerap uap air. Kadar air biochar yang tinggi akan bermasalah pada penggunaannya sebagai energi. Iskandar dan Rofiatin (2017), kadar air biochar yang rendah dapat mempercepat penyerapan air dan unsur hara.

\section{Zat Menguap Biochar}

Uji sidik ragam menunjukkan bahwa perlakuan dari jenis dan metode pembuatan berpengaruh sangat nyata terhadap zat menguap biochar. Rata-rata zat menguap biochar akibat pengaruh jenis dan metode pembuatan disajikan pada Tabel 2. 
Tabel 2. Rata-rata Zat Menguap Biochar Akibat Pengaruh Jenis dan Metode Pembuatan

\begin{tabular}{ll}
\hline \multicolumn{1}{c}{ Perlakuan } & \multicolumn{1}{c}{ Zat Menguap } \\
\cline { 2 - 2 } P1 (Bambu Petung+Metode Kon-Tiki) & $22,95 \mathrm{a}$ \\
P2 (Bambu Petung+Metode Soil pit) & $18,53 \mathrm{a}$ \\
P3 (Bambu Petung+Metode Drum) & $20,57 \mathrm{a}$ \\
P4 (Kayu Pulai+Metode Kon-Tiki) & $25,97 \mathrm{bc}$ \\
P5 (Kayu Pulai+Metode Soil pit) & $19,56 \mathrm{a}$ \\
P6 (Kayu Pulai+Metode Drum) & $21,87 \mathrm{a}$ \\
P7 (Tempurung Kelapa+Metode Kon-Tiki) & $29,29 \mathrm{c}$ \\
P8 (Tempurung Kelapa+Metode Soil pit) & $23,38 \mathrm{ab}$ \\
P9 (Tempurung Kelapa+Metode Drum) & $31,01 \mathrm{c}$ \\
\hline BNJ0,05 & 5,24
\end{tabular}

Keterangan: Angka yang diikuti oleh huruf yang tidak sama berbeda nyata pada uji $\mathrm{BNJ}_{0,05}$

Rata-rata zat menguap biochar akibat pengaruh jenis dan metode pembuatan setelah diuji dengan $\mathrm{BNJ}_{0,05}$ disajikan pada Tabel 2 menunjukkan bahwa jenis dan metode pembuatan berbeda sangat nyata terhadap zat menguap biochar. Pada semua perlakuan biochar dapat dilihat bahwa jenis biochar bambu petung dengan beberapa metode pembuatan yaitu KonTiki, soil pit, dan drum memiliki nilai rata-rata yang rendah dibandingkan dengan jenis dan metode pembuatan biochar lainnya, juga didapatkan nilai terendah pada perlakuan P2 (bambu petung dengan metode soil pit). Hal ini tergantung pada proses pembakaran biochar itu sendiri, mulai dari jenis bahan baku dan tipe alat pembakaran yang digunakan juga waktu dan suhu pembakarannya. Zat menguap juga akan berdampak pada total karbon biochar. Menurut pernyataan Pari (1995), menyebutkan bahwa tingginya kadar abu dan zat menguap juga lamanya waktu reaksi kadar zat menguap (volatile matter) dapat menurunkan kadar karbon yang terkandung dalam arang aktif, sehingga jumlah karbon yang dihasilkan semakin sedikit.

\section{Kadar Abu Biochar}

Uji sidik ragam menunjukkan bahwa perlakuan dari jenis dan metode pembuatan berpengaruh sangat nyata terhadap kadar abu biochar. Rata-rata kadar abu biochar akibat pengaruh jenis dan metode pembuatan disajikan pada Tabel 3.

Rata-rata kadar abu biochar akibat pengaruh jenis dan metode pembuatan setelah diuji dengan $\mathrm{BNJ}_{0,05}$ disajikan pada Tabel 3 menunjukkan bahwa jenis dan metode pembuatan berbeda sangat nyata terhadap kadar abu biochar. Pada semua perlakuan biochar dapat dilihat bahwa jenis biochar kayu pulai dengan beberapa metode pembuatan yaitu Kon-Tiki, soil pit, dan drum memiliki nilai rata-rata yang rendah dibandingkan dengan jenis dan metode pembuatan biochar lainnya, juga didapatkan nilai terendah pada perlakuan P4 (kayu pulai dengan metode Kon-Tiki). Hal ini diduga bahwa jenis bahan baku kayu pulai pada dasarnya berbahan keras dan memiliki kandungan lignin sekitar 18-33\%, memiliki ukuran pori meso dengan diameter rata-rata 26,87 mikrometer, juga waktu proses pembakaran yang tidak terlalu lama yaitu 65 menit dengan suhu $764{ }^{\circ} \mathrm{C}$, sehingga tidak mudah menjadi abu. Apabila kadar abu dalam biochar tersebut tinggi maka akan berdampak buruk pada kualitas/mutu biochar sendiri. Hal ini sesuai dengan pendapat Schroder (2006), kadar abu pada biochar dapat mempengaruhi mutu biochar, karena dapat menyebabkan terjadinya penyumbatan pori-pori pada biochar sehingga luas permukaannya akan menjadi sedikit. 
Mahanim et al. (2011), abu yang terdapat pada biochar merupakan oksida logam yang terdiri dari mineral yang tidak dapat menguap juga memiliki sifat sulit terbakar. Abu terdiri dari sebagian besar mineral seperti silika, alumina, besi, magnesium dan kalsium yang tidak diinginkan karena merupakan zat penghambat. Karbon paling aktif terdapat pada kandungan abu paling rendah.

Tabel 3. Rata-rata Kadar Abu Biochar Akibat Pengaruh Jenis dan Metode Pembuatan

\begin{tabular}{ll}
\hline \multicolumn{1}{c}{ Perlakuan } & \multicolumn{1}{c}{ Kadar Abu } \\
\cline { 2 - 2 } P1 (Bambu Petung+Metode Kon-Tiki) & $7,04 \mathrm{bc}$ \\
P2 (Bambu Petung+Metode Soil pit) & $8,58 \mathrm{c}$ \\
P3 (Bambu Petung+Metode Drum) & $8,08 \mathrm{c}$ \\
P4 (Kayu Pulai+Metode Kon-Tiki) & $1,80 \mathrm{a}$ \\
P5 (Kayu Pulai+Metode Soil pit) & $4,82 \mathrm{~b}$ \\
P6 (Kayu Pulai+Metode Drum) & $5,74 \mathrm{~b}$ \\
P7 (Tempurung Kelapa+Metode Kon-Tiki) & $5,85 \mathrm{~b}$ \\
P8 (Tempurung Kelapa+Metode Soil pit) & $5,40 \mathrm{~b}$ \\
P9 (Tempurung Kelapa+Metode Drum) & $8,04 \mathrm{c}$ \\
\hline BNJ0,05 & 2,38 \\
\hline Keterangan: Angka
\end{tabular}

Keterangan: Angka yang diikuti oleh huruf yang tidak sama berbeda nyata pada uji $\mathrm{BNJ}_{0,05}$

\section{Karbon Terikat (Fixed Carbon) Biochar}

Uji sidik ragam menunjukkan bahwa perlakuan dari jenis dan metode pembuatan berpengaruh sangat nyata terhadap karbon terikat biochar. Rata-rata karbon terikat biochar akibat pengaruh jenis dan metode pembuatan disajikan pada Tabel 4.

Tabel 4. Rata-rata Karbon Terikat (Fixed Carbon) Biochar Akibat Pengaruh Jenis dan Metode Pembuatan

\begin{tabular}{lc}
\hline \multicolumn{1}{c}{ Perlakuan } & Fixed Karbon \\
\cline { 2 - 2 } P1 (Bambu Petung+Metode Kon-Tiki) & $\%$ \\
P2 (Bambu Petung+Metode Soil pit) & $15,90 \mathrm{~b}$ \\
P3 (Bambu Petung+Metode Drum) & $9,95 \mathrm{a}$ \\
P4 (Kayu Pulai+Metode Kon-Tiki) & $12,49 \mathrm{a}$ \\
P5 (Kayu Pulai+Metode Soil pit) & $24,17 \mathrm{~d}$ \\
P6 (Kayu Pulai+Metode Drum) & $14,75 \mathrm{ab}$ \\
P7 (Tempurung Kelapa+Metode Kon-Tiki) & $16,12 \mathrm{~b}$ \\
P8 (Tempurung Kelapa+Metode Soil pit) & $23,44 \mathrm{~cd}$ \\
P9 (Tempurung Kelapa+Metode Drum) & $17,98 \mathrm{bc}$ \\
BNJ0,05 & $22,98 \mathrm{c}$ \\
\hline Keterangan: Angka yang dikuti oleh huruf yang tidak sama berbeda nyata pada uji BNJ
\end{tabular}

Keterangan: Angka yang diikuti oleh huruf yang tidak sama berbeda nyata pada uji $\mathrm{BNJ}_{0,05}$

Rata-rata karbon terikat (fixed carbon) biochar akibat pengaruh jenis dan metode pembuatan setelah diuji dengan $\mathrm{BNJ}_{0,05}$ disajikan pada Tabel 4 menunjukkan bahwa jenis dan metode pembuatan berbeda sangat nyata terhadap karbon terikat biochar. Pada semua perlakuan biochar dapat dilihat bahwa jenis biochar kayu pulai dengan beberapa metode 
pembuatan yaitu Kon-Tiki, soil pit, dan drum memiliki nilai yang lebih tinggi dibandingkan dengan jenis dan metode pembuatan biochar lainnya, juga didapatkan nilai tertinggi pada perlakuan P4 (kayu pulai dengan metode Kon-Tiki). Hal ini diduga bahwa kayu pulai memiliki kandungan lignin dan lama pembakarannya hanya memerlukan waktu rata-rata 65 menit, juga rendahnya kadar zat menguap. Hal ini juga terjadi karena adanya keterkaitan antara bahan baku, temperatur, dan waktu proses pembakaran yang berpengaruh terhadap nilai karbon terikat. Waktu proses berpengaruh pada nilai karbon terikat, apabila semakin lama waktu proses nilainya akan menjadi lebih kecil. Nilai karbon terikat berbanding terbalik dengan nilai kadar air dan kadar abu yang besar.

Ogawa (2006), kualitas biochar sangat bergantung pada sifat kimia dan fisik biochar yang ditentukan oleh jenis bahan baku lunak dan keras, serta metode karbonisasi (alat pembakaran, temperatur), dan bentuk biochar (padat, serbuk, karbon aktif). Kadar karbon terikat tergantung dari kadar air, kadar abu, dan kadar zat volatil dari suatu bahan. Saktiawan (2000), apabila kadar air, kadar abu dan kadar zat menguap semakin rendah maka kadar karbon terikat semakin tinggi dan nilai kalor juga semakin tinggi (Saktiawan, 2000).

Kandungan karbon yang tinggi dari biochar dapat memaksimalkan penyimpanan jumlah karbon dan dapat digunakan sebagai sumber energi atau untuk adsorpsi polutan tanah. Biochar sebagian besar terdiri dari fraksi karbon yang tahan lama telah dibuktikan sangat stabil, dengan waktu paruh lebih dari 1000 tahun di tanah (Lehmann et al., 2006). Biochar dapat menangkap karbon yang ada di udara, kemudian mentransfernya ke penyimpanan jangka panjang di tanah, dengan kata lain disebut dengan Capture Storage Carbon (CSC). Oleh karena itu, Biochar dapat membantu dalam tantangan global mitigasi karbon dioksida (CO2) (Roberts et al., 2010).

\section{KESIMPULAN DAN SARAN}

Jenis dan metode pembuatan berpengaruh terhadap karakteristik biochar yaitu kadar air biochar, zat menguap, kadar abu, dan karbon terikat (fixed carbon). Bahan baku (feedstock) biochar yang mempunyai karakteristik yang baik terdapat pada bambu petung, sedangkan metode pembuatan biochar yang terbaik terdapat pada metode Kon-Tiki.

\section{DAFTAR PUSTAKA}

Anischan. 2009. Arang Hayati "Biochar" sebagai Komponen Perbaikan Produktivitas Lahan. Iptek Tanaman Pangan Vol. 4, No. 1.

Hartanto, F.J., Alim dan Fathul. 2010. Optimasi Kondisi Operasi Pirolisis Sekam Padi Untuk Menghasilkan Bahan Bakar Briket Bioarang Sebagai Bahan Bakar Alternatif. Jurusan Teknik Kimia. Universitas Diponegoro, Semarang.

Iskandar, T. dan U. Rofiatin. 2017. Karakteristik Biochar Berdasarkan Jenis Biomasa dan Parameter Proses Pyrolisis. Jurnal Teknik Kimia. 12: 29-33.

Lehmann, J., J. Gaunt dan M. Rondon. 2006. Biochar sequestration in terrestrial ecosystems-a review. Mitigation and Adaptation Strategies for Global Change 11: 403-427.

Lehmann, J. dan S. Joseph. 2010. Biochar for Environmental Management. 2nd Ed. Earthscan Pub.Co. London, UK. Hal: 416. 
Lehmann, J., M.C. Rillig, J. Thies, C.A. Masiello, W.C. Hockaday dan D. Crowley. 2011. Biochar effects on soil biota: A review. Soil Biol. Biochem. 43:1812-1836. doi:10.1016/j.soilbio. Diakses tanggal 10 Januari 2021.

Mahanim, S., I. W. Asma, J. Rafidah, E. Puad, dan H. Shaharuddin, 2011, Production of activated carbon from industrial bamboo waste, Journal of Tropical Forest Science, 23. Hal: 417-424.

Ogawa, M. 2006. Carbon sequestration by carbonization of biomass and forestation: three case studies. Hal: 133-146.

Pari, G. 1995. Pembuatan dan Karakteristik Arang Aktif dari kayu dan Batubara. Tesis Program Pascasarjana Magister Sains Kimia. Institut Teknologi Bandung, Bandung.

Ratnaningayu. 2009. Dari timor ke krui: Bagaimana Petani dan Nelayan Menghadapi Dampak Perubahan Iklim. Pelangi Indonesia, Jakarta.

Roberts K.G., B.A Gloy, S. Joseph, N.R. Scott dan J. Lehmann. 2010. Life cycle assessment of biochar systems: estimating the energetic, economic, and climate change potential. Environmental Science and Technology. 44: 827-833.

Saktiawan, I. 2000. Identifikasi Sifat Fisik dan Kimia Briket Arang Dari Sabut Kelapa (Cocos nucifera L,). Skripsi. Jurusan Teknologi Hasil Hutan. IPB.

Schroder, E., K. Thomauske, C. Weber, A. Hornung dan V. Tumiatti. 2006. Experiment on The Generation of Activated Carbon From Biomass. Institute For Nuclear and Energy Technologies Forschungs Karlsruhe, Germany. Hal: 106-111.

Sohi, S.P., C. Lopez, E. Krull dan R. Bol. 2009. Pengaruh Konsentrasi Asam Sulfat Terhadap Sifat Fisik dan Kimia Biochar dari Sludge Biogas pada Proses Aktivasi. Universitas Brawijaya, Malang.

Tahir, S., S. Gul, S.A. Ghori, M. Sohail, S. Batool, N. Jamil dan M.R. Butt. 2008. Biochar influences growth performance and heavy metal accumulation in spinach under wastewater irrigation. Cogent Food and Agriculture. 4: 1-12.

Tang, J., W. Zhu, R. Kookana dan A. Katayama. 2013. Characteristics of biochar and its application in remediation of contaminated soil. Journal of Bioscience and Bioengineering. 116: 653-659.

Zaror, C.A. dan P.D. Pyle. 1982. The Pyrolysis of Biomass: A General Review, Sadhana Academy Proceedings in Engineering Sciences, Vol. 5, No. 4. 